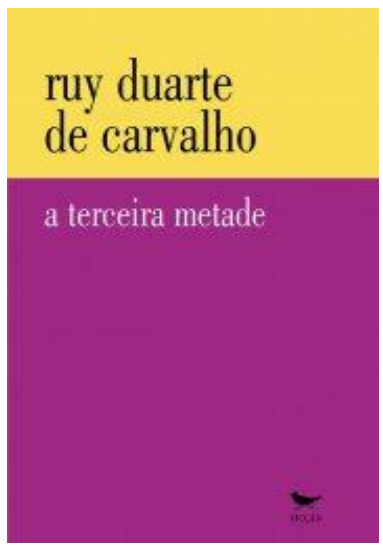

\title{
Notas sobre um romance austral
}

por Andrea Cristina Muraro ${ }^{1}$

Há muito para se dizer de um romance como A Terceira Metade (2009) de Ruy Duarte de Carvalho. Poderia começar com os possíveis diálogos com o cinema, a sensação de se estar em um roadmovie é constante.

......a passados distantes e menos distantes dava para ver dali o filme do seu romance austral... inteiramente em plongées... e trabalhando com zooms......toda a observação fixada, assestada, é um zoom..........(p.288)

Ou então, enfatizar sobre o refinamento do seu jogo artístico, entre a poesia e a ironia, a erudição e o engajamento.

.....política é política e às vezes até dá para rir... (p.394).....e afinal também, como querem que esteja agora........quem representa quem segundo a farsa e a força dessa ideia de democracia?.......quem representa nos círculos de poderes centrais, tanto de um lado como do outro desta fronteira, o meu vizinho muhimba umas vezes na margem direita e outras na margem esquerda do Kunene? (p.395)

Poderia, ainda, referir-me a essa obra como um desdobramento do projeto literário do autor; pois, retoma aqui uma multiplicidade de paisagens metamórficas $e$ metafóricas já percorridas em obras anteriores, tais como Os papeis de inglês (2000) e As paisagens propícias (2005), partes da trilogia Os filhos de Próspero, sem deixar de resgatar muito do que se lê em Desmedida (2006).

1 Doutoranda em Estudos Comparados de Literaturas de Língua Portuguesa/ FFLCH/USP. Bolsista Capes. 
Mas é melhor ir à trama. Na narrativa, autor e narrador revezam-se em filtrar os registros das memórias do protagonista, Jonas Trindade. Na composição, o autor por intermédio do narrador desloca o foco, para fazer pensar - inversamente ao usual e ao exótico - em outras possíveis imagens de África, de Angola e do africano; pois, Trindade é mucuísso, não-bantu, e portanto, como seu próprio nome anuncia, está entre, pelo menos, dois mundos: o dos brancos e o dos bantus.

.....porque condição de mucuísso ninguém reivindica, não dá vantagem nenhuma nem ser, nem dizer-se, nem ser tido como........e o que há de constar para sempre é o que ficar escrito, gravado,......este seu mais-velho Trindade está-lhe a falar assim aqui, mas se você que é doutor não registar, quem mais vai saber, mesmo agora, quanto mais mais tarde?.....(p.288)

Desse nascimento mucuísso, a infância na casa de brancos na então Moçamedes, a adolescência entre mucubais, aprendiz de cozinheiro em um hotel e cozinheiro de acampamentos com um pequeno intervalo para também poder ser ferreiro e casar-se, até tornar-se um mais-velho treinando para antepassado, o percurso do protagonista é sempre visto com surpresa pelo autor, que o encontra pela primeira vez, no Kambeno, entre Angola e Namíbia, para receber umas gravações em cassetes com rezas.

.....Trindade era quem era precisamente por ser senhor de uma
memória 'de minhoca' e de 'uma inteligência
surpreendente'.......olhando para ele agora, e ouvindo-lhe assim, o
autor não podia deixar de interrogar-se se estaria mesmo perante um
ser comum, normal.............se aquela figura, de tal estatura assim tão
reduzida, e a revelar uma tal ciência tanto de fala como de razão e de
fantasia, e de delírio até, não seria a encarnação, ali num lugar tão
imensamente distante mas tão na mesma pastoril, dessa semi-
divindade que é o Koumen dos pastores Peul do Sahel, guardião dos
rebanhos de deus, zelador dos pastos e dos animais, tanto domésticos
como dos bravios, e que aos homens não aparece senão sob a forma de
uma criança de três, sete, nove ou onze anos, no máximo............(p.25)

No julgamento do narrador, Trindade é um desses "buscadores famintos de sentido" (p.306), pois relata e revela a multidão de estrangeiros (suecos, portugueses, bôeres, belgas...), cientistas especialistas das mais diversas áreas (médico, biólogo, engenheiro, geólogo, entomologista, antropólogo...) que intentavam investigar e compreender Angola. Ao mesmo tempo, só que de outra perspectiva, o narrador procura evidenciar os espaços e as identidades destas densas ruminações de Trindade. 
Assim, esse romance pode ser lido também como uma pequena historiografia angolana, os nós da história. O Livro I, por exemplo, situa-se no período colonial e o Livro II, na sua maior parte, no período pós-independência. Há ainda um Livro III, que parece ter como objetivo, alinhavar os dois anteriores aos Três fragmentos introdutórios.

......Moçâmedes vivia nessa altura, segundo o perspicaz e sucinto comentário do nosso herói quando referiu essa época na conversa que teve com o autor, um tempo que era o de dois marcantes pós-guerras em simultâneo, embora a maioria dos povos dali, quer os brancos quer os pretos, talvez pudesse jurar-se que dificilmente estaria a dar conta fosse do que fosse......era o pós-guerra das rusgas de extermínio feitas aos mucubais, com o remanescente deles a voltar da deportação a que tinham estado sujeitos nas ilhas de São Tomé, e era o pós-guerra de uma guerra imensa, muito maior, em que os brancos se tinham envolvido uns contra os outros lá nas europas deles.... (p.73-4)

experiente já de tanta conversa com o Trindade, ninguém por certo estranhará que me tivesse então vindo logo à ideia que era agora o momento exato de recorrer a um ardil capaz de mantê-lo a falar durante o tempo todo que eu achasse necessário para rematar-lhe o discurso........haveria sempre matéria capaz de mexer seguramente outra vez com o mais- velho: o seu obstinado e apaixonado interesse pelo mar mediterrâneo e por esses brancos primordiais que tinham sido os gregos..... (p.375)

Passagens assim, vistas no conjunto do romance, ajudam a exemplificar que a composição consiste em articular a matéria artística - o que Trindade conta ao autor - ao que é recuperado desses mesmos eventos pelo narrador. Um dos méritos desse método sinuoso está em contextualizar os episódios historicamente, no continente africano, e para além dele. O que, em suma,

.....é dizer: não há passados que se revivam, tão-só passados que se refazem......(p.33)

CARVALHO, Ruy Duarte de. A terceira Metade. Lisboa: Cotovia, 2009. 